\title{
A new fluorescence turn-on probe for biothiols based on photoinduced electron transfer and its application in living cells
}

Jianxi Wang ${ }^{\mathrm{a}}$, Cheng Zhou ${ }^{\mathrm{b}}$, Jianjian Zhang ${ }^{\mathrm{a}}$, Xinyue Zhu ${ }^{\mathrm{a}}$, Xiaoyan Liu ${ }^{\mathrm{a}}$, Qin Wang ${ }^{\mathrm{b}}$, Haixia Zhang ${ }^{\mathrm{a}, *}$

${ }^{a}$ Key Laboratory of Nonferrous Metals Chemistry and Resources Utilization of Gansu Province and State Key Laboratory of Applied Organic Chemistry, College of Chemistry and Chemical Engineering, Lanzhou University, Lanzhou 730000, P. R. China.

${ }^{\mathrm{b}}$ Department of Cell Biology, School of Life Sciences, Lanzhou University, Lanzhou 730000, P. R. China.

*Corresponding author: Haixia ZHANG

Tel.: +86931 8912058;

Fax: +869318912582.

E-mail: zhanghx@lzu.edu.cn 


\section{Abstract:}

A new biothiol-selective fluorescent probe $\mathbf{1}$ based on photoinduced electron transfer (PET) mechanism was designed and synthesized. The UV-Vis absorption and fluorescent emission properties of probe $\mathbf{1}$ towards various analytes were studied in detail. The probe exhibited a large stokes shift $(\sim 200 \mathrm{~nm})$ after reacted with biothiols and could selectively detect cysteine (Cys) in dimethyl sulfoxide (DMSO)/ $\mathrm{H}_{2} \mathrm{O}$ solution (9:1, v/v, $10 \mathrm{mM}$ phosphate buffer saline, $\mathrm{pH}$ 3.5) over glutathione (GSH), homocysteine (Hcy) and other analytes with a detection limit of $0.117 \mu \mathrm{M}$. In addition, probe 1 responded well to GSH, Hcy and Cys in the same above solution with pH 5.5 and got the detection limits of $0.151 \mu \mathrm{M}, 0.128 \mu \mathrm{M}$ and $0.037 \mu \mathrm{M}$, respectively. Probe $\mathbf{1}$ was of very low cytotoxicity and successfully applied for imaging of thiols in living cells.

\section{Keywords:}

Fluorescent probe; Photoinduced electron transfer; Imaging; Biothiols 


\section{Introduction}

Recently, the selective and sensitive fluorescent probes for thiols have increasingly received attention on account of their operation simplicity and capability of imaging intracellular thiols in vivo studies. Intracellular biothiols, such as cysteine (Cys), homocysteine (Hcy) and glutathione (GSH), play momentous roles in cellular growth and redox homeostasis in biological systems through the adjustment between the reduced free thiols and oxidized disulfide forms [1-4]. In general, the abnormal level of cellular thiols is closely related to many diseases. A deficiency of Cys would cause many syndromes, like retarded growth, hair depigmentation, lethargy, liver damage, muscle and fat loss, skin lesions and weakness [5-8]. While an elevated level of Hcy in human plasma is proved to be involved in cardiovascular and Alzheimer's disease [9-11]. And GSH, the most abundant intracellular thiol, serves many cellular functions including xenobiotic metabolism, intracellular signal transduction, and gene regulation [12-17]. Therefore, it is of great scientific and technological interest to recognize and detect special sulfhydryl-containing biomolecules in biochemistry and biomedicine fields.

Over the past several decades, a lot of effective analytical methods have been developed for the detection of thiols in biological systems including high performance liquid chromatography (HPLC) [18], capillary electrophoresis [19], spectrophotometry [20], electrochemical method [21], mass spectrometry (MS) [22], and HPLC-MS [23]. Most of these methods need complicated and costly instruments and troublesome pretreatment procedures such as separation and purification before 
instrumental analyses. Moreover, few of them are convenient to be applied in intracellular tests due to their limitation in in vivo studies. Compared with these, fluorometry has its own advantages with high sensitivity, economy, real-time detection, noninvasiveness and good compatibility with biological samples. As a consequence, numerous fluorescent probes for biothiols based on various mechanisms have been developed [24], including cleavage reaction by thiols [25-34], cyclization reaction with aldehyde [35-43], Michael addition [44-54], metal complexes [55,56], nanomaterials [57-59] and others [60,61].

Rhodamine dyes are widely used as fluorescent probes owing to their high absorption coefficient and broad fluorescence in the visible region of electromagnetic spectrum, high fluorescence quantum yield and photostability [62]. For example, Li group reported a probe for $\mathrm{Hg}^{2+}$ based on rhodamine derivative bearing phthalimido Gly [63]. Das and his coworkers reported two rhodamine derivative probes for $\mathrm{Hg}^{2+}$ based on through-bond energy transfer (TBET) process [64,65] and a förster resonance energy transfer (FRET) based probe for monitoring $\mathrm{pH}$ changes in lipid-dense region of Hct116 cells [66].

Herein, we report a highly selective and sensitive fluorescent probe $\mathbf{1}$ for quantitative detection of biothiols in living cells. The probe $\mathbf{1}$ was designed basing on the cleavage of sulfonate ester by mercapto compound (RSH). The compound 2 containing rhodamine B structure is selected as the fluorophore, which has a large stokes shift and long emission wavelength. 2, 4-dinitrophenylsulfonyl moiety is chosen as the PET acceptor, which serves as not only an electrophile but also a 
quencher of compound $\mathbf{2}$ (Scheme 1).

\section{(Scheme 1)}

\section{EXPERIMENTAL SECTION}

\subsection{Materials}

Cys and GSH were purchased from Sangon Biotech. Co., LTD. (Shanghai, China). Hcy was obtained from J\&K (Beijing, China). 2, 4-Dinitrobenzenesulfonyl chloride was purchased from Alfa Aesar (Tianjin, China). Ultrapure water, which was used throughout the experiments, was obtained from an ALH-6000-U (Aquapro International Company, USA) purification system. HPLC-grade acetonitrile was purchased from Dima Technology (RichmondHill, USA). HeLa cells were obtained from Department of Cell Biology, School of Life Sciences, Lanzhou University (Lanzhou, China). All other chemicals were obtained from qualified reagent suppliers with analytical grade.

\subsection{Instruments}

Fluorescence spectra were recorded on a Fluorescence spectrophotometer RF-5301pc (SHIMADZU, Japan) with a Xenon lamp and 1.0-cm quartz cells at the slits of 10/10 nm. The fluorescence quantum yields were determined on fluorescence spectrometer FLSP920 (Edinburgh Instruments Ltd., UK). Absorption spectra were measured on a UV-Vis spectrophotometer TU-1810 (PUXI, China). Mass spectra were measured using a mass spectrometer micrOTOF II with ESI mode (Bruker, America). High resolution mass spectra (HRMS) were measured using a spectrometer APEX II 47e FT-ICR with ESI or APCI positive ion mode (Bruker Daltonics, 
America). NMR spectra were measured using a $400 \mathrm{MHz}$ instrument (JEOL, Japan). The $\mathrm{pH}$ values were measured using a digital $\mathrm{pH}$-meter PHSJ-3F (Leici, China). The fluorescence images of cells were taken using a confocal laser scanning microscope TCS SP8 (Leica, Germany) with an objective lens $(x 40)$.

\subsection{Synthesis}

Scheme S1 depicts the synthesis route of probe $\mathbf{1}$ and compound $\mathbf{2}$. Probe 1 was obtained from compound $\mathbf{3}$ and $\mathbf{4}$, both of which were synthesized according to previous reported methods $[67,68]$.

\subsubsection{Synthesis of compound 2}

Compound 3 (456.0 mg, $1.0 \mathrm{mmol}$ ) was dissolved in $10 \mathrm{~mL}$ of ethanol, and then added 4-hydroxybenzaldehyde $(122.0 \mathrm{mg}, 1.0 \mathrm{mmol})$ into the solution. The stirred mixture was heated to reflux under nitrogen for $6 \mathrm{~h}$ and then the solvent was evaporated. The solid was purified by flash column chromatography $\left(\mathrm{CH}_{2} \mathrm{Cl}_{2} / \mathrm{CH}_{3} \mathrm{OH}\right.$ $=100 / 1)$ on silica gel, affording the desired compound $\mathbf{2}$ as an offwhite solid (504.0 mg, yield 90\%). m.p. $153-155{ }^{\circ} \mathrm{C} .{ }^{1} \mathrm{H}$ NMR (400 MHz, DMSO-d 6 ): $\delta=9.90(\mathrm{~s}, 1 \mathrm{H})$, $8.79(\mathrm{~s}, 1 \mathrm{H}), 7.87(\mathrm{~d}, J=6.6 \mathrm{~Hz}, 1 \mathrm{H}), 7.61-7.51(\mathrm{~m}, 2 \mathrm{H}), 7.26(\mathrm{~d}, J=8.7 \mathrm{~Hz}, 2 \mathrm{H})$, $7.07(\mathrm{~d}, J=7.0 \mathrm{~Hz}, 1 \mathrm{H}), 6.72(\mathrm{~d}, J=8.6 \mathrm{~Hz}, 2 \mathrm{H}), 6.42(\mathrm{~d}, J=2.4 \mathrm{~Hz}, 2 \mathrm{H}), 6.40(\mathrm{~d}, J$ $=8.8 \mathrm{~Hz}, 2 \mathrm{H}), 6.32(\mathrm{dd}, J=8.9,2.4 \mathrm{~Hz}, 2 \mathrm{H}), 3.32-3.25(\mathrm{~m}, 8 \mathrm{H}), 1.07(\mathrm{t}, J=7.0 \mathrm{~Hz}$,

12H) ppm. ${ }^{13} \mathrm{C}$ NMR (100 MHz, DMSO-d 6 ): $\delta=163.89,160.11,153.19,151.63$, $149.75,148.87,134.03,129.66,129.15,128.17,126.02,124.24,123.33,116.17$, 108.42, 106.19, 97.77, 65.87, 55.45, 44.16, 12.93 ppm. HRMS (ESI, m/z) Calcd. for $\left[\mathrm{C}_{35} \mathrm{H}_{36} \mathrm{~N}_{4} \mathrm{O}_{3}+\mathrm{H}\right]^{+}:$: 561.2860, found: 561.2865. 


\subsubsection{Synthesis of probe 1}

Compound 3 (456.0 mg, $1.0 \mathrm{mmol}$ ) was dissolved in $10 \mathrm{~mL}$ ethanol, then added compound $4(352.0 \mathrm{mg}, 1.0 \mathrm{mmol})$ into the solution. The mixture was stirred and heated to reflux under nitrogen. After $6 \mathrm{~h}$, the reaction mixture was concentrated under reduced pressure to give crude solid, which was purified by silica gel column chromatography using $\mathrm{CH}_{2} \mathrm{Cl}_{2} / 0-2 \%$ methanol as eluent to afford desired brown products $\left(624.0 \mathrm{mg}\right.$, yield 79\%). m.p. $162-164{ }^{\circ} \mathrm{C} .{ }^{1} \mathrm{H}$ NMR $\left(400 \mathrm{MHz}, \mathrm{CDCl}_{3}\right) \delta=$ $8.76(\mathrm{~s}, 1 \mathrm{H}), 8.63(\mathrm{~d}, J=2.1 \mathrm{~Hz}, 1 \mathrm{H}), 8.51-8.32(\mathrm{~m}, 1 \mathrm{H}), 8.07(\mathrm{~d}, J=8.7 \mathrm{~Hz}, 1 \mathrm{H})$, $8.00-7.88(\mathrm{~m}, 1 \mathrm{H}), 7.50(\mathrm{t}, J=8.1 \mathrm{~Hz}, 4 \mathrm{H}), 7.12(\mathrm{~d}, J=7.1 \mathrm{~Hz}, 1 \mathrm{H}), 7.08(\mathrm{~d}, J=8.6$ $\mathrm{Hz}, 2 \mathrm{H}), 6.47(\mathrm{~d}, J=8.7 \mathrm{~Hz}, 2 \mathrm{H}), 6.41(\mathrm{~d}, J=2.4 \mathrm{~Hz}, 2 \mathrm{H}), 6.23(\mathrm{dd}, J=8.9,2.4 \mathrm{~Hz}$, 2H), $3.31(\mathrm{q}, J=7.1 \mathrm{~Hz}, 8 \mathrm{H}), 1.15(\mathrm{t}, J=7.0 \mathrm{~Hz}, 12 \mathrm{H}) \mathrm{ppm} .{ }^{13} \mathrm{C}$ NMR $(100 \mathrm{MHz}$, $\left.\mathrm{CDCl}_{3}\right) \delta=164.99,153.20,151.39,150.80,149.21,148.85,144.96,135.58,134.06$ $133.58,133.32,129.22,129.03,128.42,128.01,126.40,123.97,123.38,121.82$, 120.27, 107.82, 105.78, 97.67, 66.13, 44.28, 12.56 ppm. HRMS (ESI, m/z) Calcd. for $\left[\mathrm{C}_{41} \mathrm{H}_{38} \mathrm{~N}_{6} \mathrm{O}_{9}+\mathrm{H}\right]^{+}:$: 791.2494, found: 791.2477.

\subsection{General procedure for spectra measurement}

The stock solution of probe $\mathbf{1}(1.0 \mathrm{mM})$ was prepared in DMSO. The analytes (Cys, Hcy, GSH, Phe, Ala, Gly, Glu, Lys, Tyr, Trp, Ser, Asp, Val, Ile, His and $\mathrm{CN}^{-}$) solutions $(8.0 \mathrm{mM})$ were prepared in deionized water. The test concentration of probe 1 was 10 $\mu \mathrm{M}$ by diluting the stock solution to $4 \mathrm{~mL}$ DMSO/ $\mathrm{H}_{2} \mathrm{O}$ solution (9: 1, v/v, $10 \mathrm{mM}$ phosphate buffer saline (PBS)) at various $\mathrm{pH}$. The resulting solution was shaken well at $37{ }^{\circ} \mathrm{C}$ for $80 \mathrm{~min}$, and then the fluorescence and UV absorption spectra were 
recorded. Fluorescence spectra were measured using a fluorescence spectrometer $\left(\lambda_{\mathrm{ex}}\right.$ $=328 \mathrm{~nm}$, slit: 10/10 nm).

\subsection{Cell culture}

HeLa cells were grown in Dulbecco's Modified Eagle Medium (DMEM) supplemented with heat-inactivated fetal bovine serum $(10 \%)$, penicillin $(100 \mathrm{U} / \mathrm{mL})$, and streptomycin $(100 \mathrm{U} / \mathrm{mL})$ at $37{ }^{\circ} \mathrm{C}$ in a $95 \%$ humidity atmosphere under $5 \% \mathrm{CO}_{2}$ environment.

\subsection{Confocal microscope imaging}

The cells were seeded in $35 \mathrm{~mm}$ diameter glass-bottomed dishes at a density of $3 \times$ $10^{5}$ cells per dish in RPMI 1640 medium for $24 \mathrm{~h}$. For living cells imaging experiment of probe 1, cells were incubated with $20 \mu \mathrm{M}$ probe $\mathbf{1}$ for $45 \mathrm{~min}$ at $37^{\circ} \mathrm{C}$ and washed three times with the PBS (pH 5.5 at $37{ }^{\circ} \mathrm{C}$ containing $1 \%$ DMSO), and then imaged. For N-methylmaleimide (NMM, a thiol blocking agent) treated experiments, HeLa cells were pretreated with $\mathrm{NMM}(1 \mathrm{mM})$ for $30 \mathrm{~min}$ at $37{ }^{\circ} \mathrm{C}$, washed three times with the PBS, and then incubated with $20 \mu \mathrm{M}$ probe 1 (or incubated with $200 \mu \mathrm{M}$ of Cys, GSH or Hcy for $30 \mathrm{~min}$ prior to addition of probe 1) for $45 \mathrm{~min}$ at $37^{\circ} \mathrm{C}$. Cell imaging was then carried out after washing cells three times with the PBS.

\subsection{Cytotoxicity assay}

The cytotoxic effects of probe $\mathbf{1}$ and compound $\mathbf{2}$ were determined by MTT (3-(4,5-dimethyl-2-thiazolyl)-2,5-diphenyl-2-H-tetrazolium bromide) assays. HeLa cells $\left(1 \times 10^{4}\right.$ cells/well $)$ were placed in a flat bottom 96 -well plate in $100 \mu \mathrm{L}$ culture medium and incubated in $5 \% \mathrm{CO}_{2}$ at $37{ }^{\circ} \mathrm{C}$ for $24 \mathrm{~h}$. The cells were treated with probe 
$1(0-80 \mu \mathrm{M})$ and compound 2 respectively for $24 \mathrm{~h}$, then MTT solution $(5.0 \mathrm{mg} / \mathrm{mL}$, PBS) was added into each well $(10 \mu \mathrm{L} /$ well, $0.5 \mathrm{mg} / \mathrm{mL})$ and the residual MTT solution was removed after $4 \mathrm{~h}$. After shaking for $10 \mathrm{~min}$, the absorbance values of the wells were recorded using a microplate reader at $490 \mathrm{~nm}$. The cytotoxic effect (VR) of probe 1 and compound 2 were assessed using the following equation: $\mathrm{VR}=\mathrm{A} / \mathrm{A}_{0} \times$ $100 \%$, where $\mathrm{A}$ and $\mathrm{A}_{0}$ were the absorbance of the experimental group and control group, respectively. The assays were performed in six sets for each concentration.

\section{Results and discussion}

\subsection{Synthesis of probe 1}

Both probe 1 and compound $\mathbf{2}$ were obtained by the reaction between aldehyde and amine under the heat and reflux condition in ethanol with a yield of $79 \%$ and $90 \%$, respectively. The chemical structures of probe $\mathbf{1}$ and compound $\mathbf{2}$ were confirmed by

${ }^{1} \mathrm{H}-\mathrm{NMR},{ }^{13} \mathrm{C}-\mathrm{NMR}$, and HRMS (ESI), as shown in supporting information (Fig. S12-S17).

\subsection{Effect of $p H$}

The $\mathrm{pH}$ dependence of the thiol-induced increase of fluorescent intensity at $520 \mathrm{~nm}$ was investigated. As shown in Fig. 1, the fluorescence of probe $\mathbf{1}$ enhanced gradually when $\mathrm{pH} \geq 6$. The $\mathrm{pH}$ titration spectra were provided in Fig. S2. On the other hand, upon the addition of Cys, GSH or Hcy, a large emission enhancement was observed over a wide $\mathrm{pH}$ range of 4-10. There was little emission enhancement of probe 1 upon addition of $\mathrm{RSH}$ when $\mathrm{pH} \leq 3.5$. These findings proved that probe $\mathbf{1}$ could be used for selective detection of biothiols within physiological $\mathrm{pH}$ range. We studied the 
fluorescent responses at $\mathrm{pH} 5.5$ or 3.5 to further verify these results.

(Fig. 1)

The spectral properties of probe 1 were measured in the DMSO/ $\mathrm{H}_{2} \mathrm{O}$ solution $(9: 1$, v/v, $10 \mathrm{mM}$ PBS). At pH 3.5 (Fig. S1A and S1B), probe 1 showed two absorption bands at $277 \mathrm{~nm}$ and $315 \mathrm{~nm}\left(\varepsilon=3.47 \times 10^{4} \mathrm{M}^{-1} \mathrm{~cm}^{-1}\right)$ and weak fluorescence $(\Phi=$ 0.010, Table S1). Upon the addition of Cys, the absorption at $277 \mathrm{~nm}$ enhanced and a new absorption maximum $321 \mathrm{~nm}$ appeared with a $6 \mathrm{~nm}$ red shift compared with probe 1 itself. The resulting absorption spectrum was similar with that of compound 2 (the expected product, $\lambda_{\max }=321 \mathrm{~nm}, \varepsilon=4.15 \times 10^{4} \mathrm{M}^{-1} \mathrm{~cm}^{-1}$ ). Meanwhile, a remarkable enhanced fluorescence emission peak at $518 \mathrm{~nm}$ appeared after probe $\mathbf{1}$ reacted with Cys, which was same as that of compound $2(\Phi=0.029)$. The similar results were obtained at pH 5.5 (Fig. S1C and S1D, Table S1).

\subsection{Response time of probe 1 to biothiols}

To achieve a better understanding of the reaction rate, we also carried out time-dependent analysis of probe 1 with thiols at $37{ }^{\circ} \mathrm{C}$. The fluorescent intensity at $520 \mathrm{~nm}$ was plotted $v$ s time. As depicted in Fig. 2, at $\mathrm{pH} 3.5$, probe 1 only observably responded to Cys and the equilibrium was gotten within 80 min. However, probe 1 responded to the three mercapto compounds at $\mathrm{pH} 5.5$ but showed a much slower equilibrium for GSH and Hcy than Cys. This suggested that probe $\mathbf{1}$ could differentiate Cys from the others according to the reaction rate at $\mathrm{pH} 3.5$. Pitman et al. reported that the pKa of the sulfhydryl groups on Cys, Hcy and GSH are 8.35, 8.87 and 8.75, respectively [69]. According to these pKa values, Cys should be dissociated 
more easily than Hcy and GSH. In addition, Wang et al. reported that Cys has stronger reducing ability [70]. Cys should be a stronger nucleophile. Therefore, probe $\mathbf{1}$ is more reactive towards Cys. The long response equilibrium time to thiols was perhaps owing to the large structure of probe 1, which would not greatly influence its application. There are some probes reported which need long response equilibrium time to analytes, such as a probe for the detection of hydrogen sulfide which needed 80 min [71] and another probe for detecting GSH whose response equilibrium time was over $90 \min [72]$.

\section{(Fig. 2)}

\subsection{Specificity of probe 1}

To investigate the ability of probe $\mathbf{1}$ to discriminate thiols from other analytes, the selectivity experiments were carried out using natural amino acids (Ala, Glu, Asp, Gly, His, Ile, Tyr, Lys, Phe, Trp, Ser, Val) and $\mathrm{CN}^{-}$. As illustrated in Fig. 3 and Fig. S3, probe 1 could selectively detect $\mathrm{Cys}$ at $\mathrm{pH} 3.5$, and as well as Cys, GSH and Hcy at pH 5.5.

(Fig. 3)

\subsection{Quantitative responses of probe 1 to thiols}

In order to measure the fluorescence sensitivity of probe $\mathbf{1}$ for thiols, fluorescence and UV titration were carried out (Fig. 4, Fig. S4-S7). As shown in Fig. 4, at pH 3.5, the fluorescent intensity at $520 \mathrm{~nm}$ gradually increased with the increase of the concentration of Cys. The fluorescent intensity of probe 1-Cys solution was linearly proportional to the amount of Cys added. The limit of detection (LOD) calculated by 
the formula $(3 \sigma / k)$ was $0.117 \mu \mathrm{M}$, where $\sigma$ is the standard deviation of blank measurements and $k$ is the slope obtained from the calibration curve. With increasing concentration of Cys, the UV absorption of probe $\mathbf{1}$ enhanced with a red shift. Similar phenomena were observed in the titration experiments of probe 1 to $\mathrm{Cys}$, GSH and Hcy at $\mathrm{pH}$ 5.5. The LODs were $0.037 \mu \mathrm{M}$ for Cys, $0.151 \mu \mathrm{M}$ for GSH, $0.128 \mu \mathrm{M}$ for Hcy, respectively. The probe $\mathbf{1}$ was demonstrated to be a sensitive fluorescent sensor for the quantitative detection of biothiols.

(Fig. 4)

\subsection{Study on sensing mechanism}

The mechanism of probe 1 responding to biolthiols is based on cleavage of $\mathrm{O}-\mathrm{S}$ by hydrosulfuryl, which generates compound $\mathbf{2}, \mathrm{SO}_{2}$ and compound 5 (Scheme 1). In order to further confirm the sensing mechanism, HPLC analysis was performed (Fig. S8). The decrease of probe 1 signal was observed after mixing 5.0 equiv Cys, while the signal ascribed to compound $\mathbf{2}$ appeared. In addition, the mass spectrometry analysis of probe $\mathbf{1}(10 \mu \mathrm{M})$ treated with Cys (20 equiv) also demonstrated the generation of expected compound 2 (m/z 561.2373) (Fig. S9). Moreover, the product of probe 1 with Cys was isolated and checked by thin layer chromatography (TLC). The results showed that the reaction did produce the compound 2 (Fig. S10).

To further explain the fluorescence "off-on" process, the structures of probe $\mathbf{1}$ and compound 2 were optimized and their frontier molecular orbital energies were calculated by using Gaussian 09 [DFT at the B3LYP/6-311G (d, p) level] [73,74]. As shown in Fig. 5, the HOMO and LUMO levels support a possible PET process in 
probe 1. The electron transfer from compound 2 fragment (PET donor) to the 2,4-dinitrophenylsulfonyl (PET acceptor) diminishes the fluorescence of the original fluorophore, resulting in fluorescence being "switched off". However, the thiol-promoted specific $\mathrm{O}-\mathrm{S}$ cleavage of probe $\mathbf{1}$ releases free compound 2, which eliminates the PET fluorescence quenching process. As a result, the fluorescence is "switched on". Furthermore, the energy gaps (HOMO-LUMO) of probe $\mathbf{1}$ and compound 2 were calculated as $1.40 \mathrm{ev}$ and $3.71 \mathrm{ev}$, respectively. The difference of the energy gaps also indicates the PET process.

\section{(Fig. 5)}

\subsection{Fluorescence microscopic images in living cells and cell viability}

Confocal microscopy experiments were carried out with living Hela cells to detect intracellular thiols by probe 1. As shown in Fig. 6, Hela cells show no intracellular background fluorescence. After Hela cells were incubated with probe $\mathbf{1}(20 \mu \mathrm{M})$ for 45 min at $37{ }^{\circ} \mathrm{C}$, green fluorescence could be observed inside the cells. In contrast, in the control experiment, the cells were treated with NMM and the probe subsequently and a remarkable fluorescence quenching was observed. The cells treated with NMM followed by thiols and probe $\mathbf{1}$ displayed green fluorescence again. These results reveal that probe 1 can penetrate cell membranes and could be applied for thiol imaging in living cells.

The cytotoxicity of probe $\mathbf{1}$ in HeLa cells was determined by the MTT assay (Fig. S11). Upon exposure to probe $1(0-80 \mu \mathrm{M})$ and compound 2 for $24 \mathrm{~h}$, over $90 \%$ of the HeLa cells remained viable, which indicated that the probe $\mathbf{1}$ was of very low toxicity 
and suitable for imaging of thiols in living cells.

(Fig. 6)

\section{Conclusion}

In summary, a new turn-on fluorescent probe was successfully designed and synthesized basing on PET for selective detection of thiols. Probe $\mathbf{1}$ exhibited a large stokes shift $(\sim 200 \mathrm{~nm})$ after reacted with thiols and could selectively detect Cys at $\mathrm{pH}$ 3.5, and responded well to GSH, Hcy and Cys at $\mathrm{pH} 5.5$, too. Probe 1 is of very low cytotoxicity and good cell permeability, which could be applied in the fluorescence imaging of thiols in living cells.

\section{Acknowledgment}

This work was supported by National Science Foundation of China (no. 21375052, 21575055).

\section{References}

[1] Krauth-Siegel RL, Bauer H, Schirmer RH. Dithiol proteins as guardians of the intracellular redox milieu in parasites: old and new drug targets in trypanosomes and malaria-causing plasmodia. Angew Chem Int Ed 2005;44:690-715.

[2] Ball RO, Courtney-Martin G, Pencharz PB. The in vivo sparing of methionine by cysteine in sulfur amino acid requirements in animal models and adult humans. J Nutr 2006;136:1682s-93s.

[3] Hong R, Han G, Fernandez JM, Kim BJ, Forbes NS, Rotello VM. Glutathione mediated delivery and release using monolayer protected nanoparticle carriers. J Am Chem Soc 2006;128:1078-9. 
[4] Wood ZA, Schroder E, Harris JR, Poole LB. Structure, mechanism and regulation of peroxiredoxins. Trends Biochem Sci 2003;28:32-40.

[5] Shahrokhian S. Lead phthalocyanine as a selective carrier for preparation of a cysteine-selective electrode. Anal Chem 2001;73:5972-8.

[6] Kannana P, John SA. Ultrasensitive detection of L-Cysteine using gold 5-amino-2-mercapto-1, 3, 4-thiadiazole core-shell nanoparticles film modified electrode. Biosens Bioelectron 2011;30:276-81.

[7] Deng L, Wu WT, Guo HM, Zhao JZ, Ji SM, Zhang XY. Colorimetric and ratiometric fluorescent chemosensor based on diketopyrrolopyrrole for selective detection of thiols: an experimental and theoretical study. J Org Chem 2011;76:9294-304.

[8] Shao N, Jin JY, Cheung SM, Yang RH, Chan WH, Mo T. A spiropyran-based ensemble for visual recognition and quantification of cysteine and homocysteine at physiological levels. Angew Chem Int Ed 2006;45:4944-8.

[9] Refsum H, Ueland PM, Nygard O, Vollset SE. Homocysteine and cardiovascular disease. Annu Rev Med 1998;49:31-62.

[10] Seshadri S, Beiser A, Selhub J, Jacques PF, Rosenberg IH, D’Agostino RB, Wilson PWF, Wolf PAN. Plasma homocysteine as a risk factor for dementia and Alzheimer's disease. Engl J Med 2002;346:476-83.

[11] Lee HY, Choi YP, Kim S, Yoon T, Guo ZQ, Lee S, Swamy KMK, Kim G, Lee JY, Shin I, Yoon J. Selective homocysteine turn-on fluorescent probes and their bioimaging applications. Chem Commun 2014;50:6967-9.

[12] Yin CX, Huo FJ, Zhang JJ, Martínez-M, Yang YT, Lv HG, Li SD. Thiol-addition reactions 
and their applications in thiol recognition. Chem Soc Rev 2013;42:6032-59.

[13] Yang YT, Huo FJ, Yin CX, Zheng AM, Chao JB. Thiolechromene click chemistry: a coumarin-based derivative and its use as regenerable thiol probe and in bioimaging applications. Biosens Bioelectron 2013;47:300-6.

[14] Wang CH, Sinskey AJ, Lodish HF. Oxidized redox state of glutathione in the endoplasmic reticulum. Science 1992;257:1496-502.

[15] Dalton TP, Shertzer HG, Puga A. Regulation of gene expression by reactive oxygen. Annu Rev Pharmacol Toxicol 1999;39:67-101.

[16] Pullela PK, Chiku T, Carvan MJ, Sem DS. Characterization of a novel dithiocarbamate glutathione reductase inhibitor and its use as a tool to modulate intracellular glutathione. Anal Biochem 2006;352:265-73.

[17] Yin J, Kwon Y, Kim D, Lee D, Kim G, Hu Y, Ryu JH, Yoon J. Cyanine-based fluorescent probe for highly selective detection of glutathione in cell cultures and live mouse tissues. J Am Chem Soc 2014;136:5351-8.

[18] Ivanov AR, Nazimov IV, Baratova LA. Qualitative and quantitative determination of biologically active low-molecular-mass thiols in human blood by reversed-phase high-performance liquid chromatography with photometry and fluorescence detection. J Chromatogr A 2000;870:433-42.

[19] Inoue T, Kirchhoff JR. Determination of thiols by capillary electrophoresis with amperometric detection at a coenzyme pyrroloquinoline quinone modified electrode. Anal Chem 2002;74:1349-54.

[20] Liang GL, Ronald J, Chen YX, Ye DJ, Pandit P, Ma ML, Rutt B, Rao JH. Controlled 
Self-Assembling of Gadolinium Nanoparticles as Smart Molecular Magnetic Resonance Imaging Contrast Agents. Angew Chem Int Ed 2011;50:6283-6.

[21] Wang W, Li L, Liu SF, Ma CP, Zhang SS. Determination of physiological thiols by electrochemical detection with piazselenole and its application in rat breast cancer cells 4T-1. J Am Chem Soc 2008;130:10846-7.

[22] Xu KH, Zhang Y, Tang B, Laskin J, Roach PJ, Chen H. Study of highly selective and efficient thiol derivatization using selenium reagents by mass spectrometry. Anal Chem 2010;82:6926-32.

[23] Seiwert B, Karst U. Simultaneous LC/MS/MS determination of thiols and disulfides in urine samples based on differential labeling with ferrocene-based maleimides. Anal Chem 2007;79:7131-8.

[24] Peng H, Chen W, Cheng Y, Hakuna L, Strongin R, Wang B. Thiol reactive probes and chemosensors. Sensors 2012;12:15907-46.

[25] Peng L, Zhou ZJ, Wei RR, Li K, Song PS, Tong AJ. A fluorescent probe for thiols based on aggregation-induced emission and its application in live-cell imaging. Dyes Pigm $2014 ; 108: 24-31$.

[26] Maeda H, Matsuno H, Ushida M, Katayama K, Saeki K, Itoh N. 2,4-Dinitrobenzenesulfonyl fluoresceins as fluorescent alternatives to Ellman's reagent in thiol-quantification enzyme assays. Angew Chem Int Ed 2005;44:2922-5.

[27] Long LL, Lin WY, Chen BB, Gao WS, Yuan L. Construction of a FRET-based ratiometric fluorescent thiol probe. Chem Commun 2011;47:893-5.

[28] Lee MH, Han JH, Kwon PS, Bhuniya S, Kim JY, Sessler JL, Kang, C, Kim, JS. Hepatocyte-targeting single galactose-appended naphthalimide: a tool for intracellular thiol 
imaging in vivo. J Am Chem Soc 2012;134:1316-22.

[29] Lim CS, Masanta G, Kim HJ, Han JH, Kim HM, Cho BR. Ratiometric detection of mitochondrial thiols with a two-photon fluorescent probe. J Am Chem Soc 2011;133(29):11132-5.

[30] Tang B, Xing YL, Li P, Zhang N, Yu FB, Yang GW. A rhodamine-based fluorescent probe containing a Se-N bond for detecting thiols and its application in living cells. J Am Chem Soc 2007;129:11666-7.

[31] Wei MJ, Yin P, Shen YM, Zhang LL, Deng JH, Xue SY, Li HT, Guo B, Zhang YY, Yao SZ. A new turn-on fluorescent probe for selective detection of glutathione and cysteine in living cells. Chem Commun 2013; 49: 4640-2.

[32] Shiu HY, Wong MK, Che CM. "Turn-on" FRET-based luminescent iridium(III) probes for the detection of cysteine and homocysteine. Chem Commun 2011;47:4367-9.

[33] Chen YH, Zhao JZ, Guo HM, Xie LJ. Geometry relaxation-induced large stokes shift in red-emitting borondipyrromethenes (BODIPY) and applications in fluorescent thiol probes. J Org Chem 2012;77:2192-206.

[34] Shao JY, Sun HY, Guo HM, Ji SM, Zhao JZ, Wu WT, Yuan XL, Zhang CL, James TD. A highly selective red-emitting FRET fluorescent molecular probe derived from BODIPY for the detection of cysteine and homocysteine: an experimental and theoretical study. Chem Sci 2012;3:1049-61.

[35] Lee KS, Kim TK, Lee JH, Kim HJ, Hong JI. Fluorescence turn-on probe for homocysteine and cysteine in water. Chem Commun 2008;(46):6173-5.

[36] Lim S, Escobedo JO, Lowry M, Xu XY, Strongin R. Selective fluorescence detection of cysteine and N-terminal cysteine peptide residues. Chem Commun 2010;46:5707-9. 
[37] Yuan L, Lin WY, Yang YT. A ratiometric fluorescent probe for specific detection of cysteine over homocysteine and glutathione based on the drastic distinction in the kinetic profiles. Chem Commun 2011;47:6275-7.

[38] Liu XM, Xi N, Liu SJ, Ma Y, Yang HR, Li HR, He JH, Zhao Q, Li FY, Huang W. Highly selective phosphorescent nanoprobes for sensing and bioimaging of homocysteine and cysteine. $\mathrm{J}$ Mater Chem 2012;22:7894-901.

[39] Hu MM, Fan JL, Li HL, Song KD, Wang S, Cheng GH, Peng XJ. Fluorescent chemodosimeter for Cys/Hcy with a large absorption shift and imaging in living cells. Org Biomol Chem 2011;9:980-3.

[40] Wang P, Liu J, Lv X, Liu YL, Zhao Y, Guo W. A naphthalimide-based glyoxal hydrazone for selective fluorescence turn-on sensing of Cys and Hcy. Org Lett 2012;14:520-3.

[41] Zhang X, Ren X, Xu QH, Loh KP, Chen ZK. One- and two-photon turn-on fluorescent probe for cysteine and homocysteine with large emission shift. Org Lett 2009;11:1257-60.

[42] Zhang M, Li MY, Zhao Q, Li FY, Zhang DQ, Zhang JP, Yi T, Huang CH. Novel Y-type two-photon active fluorophore: synthesis and application in fluorescent sensor for cysteine and homocysteine. Tetrahedron Lett 2007;48:2329-33.

[43] Das P, Mandal AK, Chandar NB, Baidya M, Bhatt HB, Ganguly B, et al. New chemodosimetric reagents as ratiometric probes for cysteine and homocysteine and possible detection in living cells and in blood plasma. Chem Eur J 2012;18:15382-93.

[44] Yang YT, Huo FJ, Yin CX, Chao JB, Zhang YB. An 'OFF-ON' fluorescent probe for specially recognize on Cys and its application in bioimaging. Dyes Pigm 2015;114:105-9.

[45] Xue SH, Ding SS, Zhai QS, Zhang HY, Feng GQ. A readily available colorimetric and 
near-infrared fluorescent turn-on probe for rapid and selective detection of cysteine in living cells. Biosens Bioelectron 2015;68:316-21.

[46] Zhang RR, Zhang JF, Wang SQ, Cheng YL, Miao JY, Zhao BX. Novel pyrazoline-based fluorescent probe for detecting thiols and its application in cells. Spectrochim Acta A. 2015;137:450-5.

[47] Shi JM, Wang YJ, Tang XL, Liu W, Jiang H, Dou W, Liu WS. A colorimetric and fluorescent probe for thiols based on 1, 8-naphthalimide and its application for bioimaging. Dyes Pigm 2014;100:255-60.

[48] Liu YB, Liu YW, Liu W, Liang SC. Two-photon fluorescent probe derived from naphthalimide for cysteine detection and imaging in living cells. Spectrochim Acta A. 2015;137:509-15.

[49] Jung HS, Han JH, Habata Y, Kang C, Kim JS. An iminocoumarin-Cu(II) ensemble-based chemodosimeter toward thiols. Chem Commun 2011;47:5142-4.

[50] Kwon H, Lee K, Kim HJ. Coumarin-malonitrile conjugate as a fluorescence turn-on probe for biothiols and its cellular expression. Chem Commun 2011;47:1773-5.

[51] Wang HL, Zhou GD, Gai HW, Chen XQ. A fluorescein-based probe with high selectivity to cysteine over homocysteine and glutathione. Chem Commun 2012;48:8341-3.

[52] Das P, Mandal AK, Reddy GU, Baidya M, Ghosh SK, Das A. Designing a thiol specific fluorescent probe for possible use as a reagent for intracellular detection and estimation in blood serum: kinetic analysis to probe the role of intramolecular hydrogen bonding. Org Biomol Chem 2013;11:6604-14.

[53] A AH, G UR, Ali F, Taye N, Chattopadhyay S, Das A. A reagent for specific recognition of 
cysteine in aqueous buffer and in natural milk: imaging studies, enzymatic reaction and analysis of whey protein. Chem Commun 2015;51:15592-5.

[54] Ali F, H AA, Taye N, Gonnade RG, Chattopadhyay S, Das A. A fluorescent probe for specific detection of cysteine in the lipid dense region of cells. Chem Commun 2015;51:16932-5.

[55] Wang SJ, Ma HM, Li J, Chen XQ, Bao ZJ, Sun SN. Direct determination of reduced glutathione in biological fluids by Ce(IV)-quinine chemiluminescence. Talanta 2006;70:518-21.

[56] Reddy GU, Agarwalla H, Taye N, Ghorai S, Chattopadhyay S, Das A. A novel fluorescence probe for estimation of cysteine/histidine in human blood plasma and recognition of endogenous cysteine in live Hct116 cells. Chem Commun 2014;50:9899-902.

[57] Sudeep PK, Joseph STS, Thomas KG. Selective detection of cysteine and glutathione using gold nanorods. J Am Chem Soc 2005;127:6516-7.

[58] Huang R, Wang XJ, Wang DL, Liu F, Mei B, Tang AM, Jiang J, Liang GL. Multifunctional fluorescent probe for sequivuential detections of glutathione and caspase- 3 in vitro and in cells. Anal Chem 2013;85:6203-7.

[59] Yuan Y, Zhang J, Wang MJ, Mei B, Guan YF, Liang GL. Detection of glutathione in vitro and in cells by the controlled self-assembly of nanorings. Anal Chem 2013;85:1280-4.

[60] Roubinet B, Renard P-Y, Romieu A. New insights into the water-solubilization of thiol-sensitive fluorogenic probes based on long-wavelength 7-hydroxycoumarin scaffolds. Dyes Pigm 2014;110:270-84.

[61] Kim Y, Choi M, Seo S, Manjare ST, Jon S, Churchill DG. A selective fluorescent probe for cysteine and its imaging in live cells. RSC Adv 2014;4:64183-6.

[62] Beija M, Afonso CA, Martinho JM. Synthesis and applications of rhodamine derivatives as 
fluorescent probes. Chem Soc Rev 2009;38:2410-33.

[63] Yan F, Wang M, Cao D, Yang N, Ma B, Chen L. Recognition preference of rhodamine derivative bearing phthalimido Gly for by UV-Vis and fluorescence spectroscopy. Journal of Spectroscopy. 2013;2013:1-7.

[64] Saha S, Mahato P, Baidya M, Ghosh SK, Das A. An interrupted PET coupled TBET process for the design of a specific receptor for $\mathrm{Hg}^{2+}$ and its intracellular detection in MCF7 cells. Chem Commun 2012;48:9293-5.

[65] Reddy GU, Ramu V, Roy S, Taye N, Chattopadhyay S, Das A. A specific probe for $\mathrm{Hg}^{2+}$ to delineate even $\mathrm{H}^{+}$in pure aqueous buffer/Hct116 colon cancer cells: $\mathrm{Hg}(\mathrm{II})-\eta^{2}$-arene $\pi$-interaction and a TBET-based fluorescence response. Chem Commun 2014;50:14421-4.

[66] Reddy G U, A AH, Ali F, Taye N, Chattopadhyay S, Das A. FRET-Based probe for monitoring pH changes in lipid-dense region of Hct116 cells. Org Lett 2015;17:5532-5.

[67] Zhang JJ, Yu BF, Ning, LL, Zhu XY, Wang JX, Chen ZJ, Liu XY, Yao XJ, Zhang XY, Zhang HX. A near-infrared fluorescence probe for thiols based on analyte-specific cleavage of carbamate and its application in bioimaging. Eur J Org Chem 2015;2015:1711-8.

[68] Xiang Y, Tong AJ, Jin PY, Ju Y. New fluorescent rhodamine hydrazone chemosensor for $\mathrm{Cu}(\mathrm{II})$ with high selectivity and sensitivity. Org Lett 2006;8:2863-6.

[69] Pitman IH, Morris IJ. Covalent additions of glutathione, cysteine, homocysteine, cysteamine and thioglycolic acid to quinazoline cation. Aust J Chem 1979;32:1567-73.

[70] Peng H, Wang K, Dai C, Williamson S, Wang B. Redox-based selective fluorometric detection of homocysteine. Chem Commun 2014;50:13668-71.

[71] Gu B, Mi NX, Zhang YY, Yin P, Li HT, Yao SZ. A tetraphenylimidazole-based fluorescent 
probe for the detection of hydrogen sulfide and its application in living cells. Anal Chim Acta 2015;879:85-90.

[72] Chen CY, Liu W, Xu C, Liu WS. A colorimetric and fluorescent probe for detecting intracellular GSH. Biosens Bioelectron 2015;71:68-74.

[73] Yuan L, Lin WY, Zhao S, Gao WS, Chen B, He LW, Zhu SS. A unique approach to development of near-infrared fluorescent sensors for in vivo imaging. J Am Chem Soc 2012;134:13510-23.

[74] Guo HM, Jing YY, Yuan XL, Ji SM, Zhao JZ, Li XH, Kan YY. Highly selective fluorescent OFF-ON thiol probes based on dyads of BODIPY and potent intramolecular electron sink 2,4-dinitrobenzenesulfonyl subunits. Org Biomol Chem 2011;9:3844-53. 


\section{Figure and Scheme captions}

Scheme 1. Proposed sensing mechanism of probe 1 to biothiols.

Fig. 1. The fluorescent intensity of probe $1(10 \mu \mathrm{M})$ in the absence and presence of 15 equiv Cys, GSH, Hcy at various pH after $80 \min \left(\lambda_{\text {ex }}=328 \mathrm{~nm}\right.$, slit: $\left.10 / 10 \mathrm{~nm}\right)$.

Fig. 2. Time-dependent fluorescence intensities of probe $\mathbf{1}(10 \mu \mathrm{M})$ at $520 \mathrm{~nm}$ in presence of 15 equiv thiols in DMSO/ $\mathrm{H}_{2} \mathrm{O}$ solution (9: 1, v/v, $10 \mathrm{mM}$ PBS) at $37^{\circ} \mathrm{C}$. (A) $\mathrm{pH} 3.5$, (B) $\mathrm{pH} 5.5$.

Fig. 3. Fluorescence responses of probe $\mathbf{1}(10 \mu \mathrm{M})$ to various analytes (15 equiv), Ala, Glu, Asp, Gly, His, Ile, Tyr, Lys, Phe, Trp, Ser, Val, Cys, Hcy, GSH and $\mathrm{CN}^{-}$for 80 min in DMSO/ $\mathrm{H}_{2} \mathrm{O}$ solution (9: 1, v/v, $10 \mathrm{mM}$ PBS). (A) pH 3.5, (B) pH 5.5.

Fig. 4. (A) Fluorescence titration of probe $1(10 \mu \mathrm{M})$ upon addition of Cys (0-15.0 equiv) at $\mathrm{pH}$ 3.5. (B) A linear relationship of fluorescence intensity changes at $520 \mathrm{~nm}$ of probe $\mathbf{1}$ against [Cys] from 0 to $100 \mu \mathrm{M}$. LOD $(3 \sigma / \mathrm{k})$ calculated as $0.117 \mu \mathrm{M}$.

Fig. 5. Density functional theory (DFT) optimized structures and frontier molecular orbitals (MOs) of (A) probe $\mathbf{1}$ and (B) compound 2. Calculations were based on ground state geometry by DFT at the B3LYP/6-311G (d, p)/level using Gaussian 09.

Fig. 6. Confocal microscope images of probe 1 in HeLa cells at pH 5.5. (A) Blank HeLa cells. (B) HeLa cells incubated with probe $\mathbf{1}(20 \mu \mathrm{M})$ for 45 min. (C) HeLa cells pretreated with NMM (1 $\mathrm{mM})$ for $30 \mathrm{~min}$ and followed with probe $\mathbf{1}(20 \mu \mathrm{M})$ for $45 \mathrm{~min}$. (D) HeLa cells pretreated with NMM $(1 \mathrm{mM})$ for $30 \mathrm{~min}$ and then with GSH $(200 \mu \mathrm{M})$ for $30 \mathrm{~min}$ and with probe $\mathbf{1}(20 \mu \mathrm{M})$ for 45 min. (E) Same as (D) except replacing GSH with Hcy. (F) Same as (D) except replacing GSH with Cys. Top: Differential interference contrast (DIC) images; Middle: Fluorescence images; Bottom: Merge. 


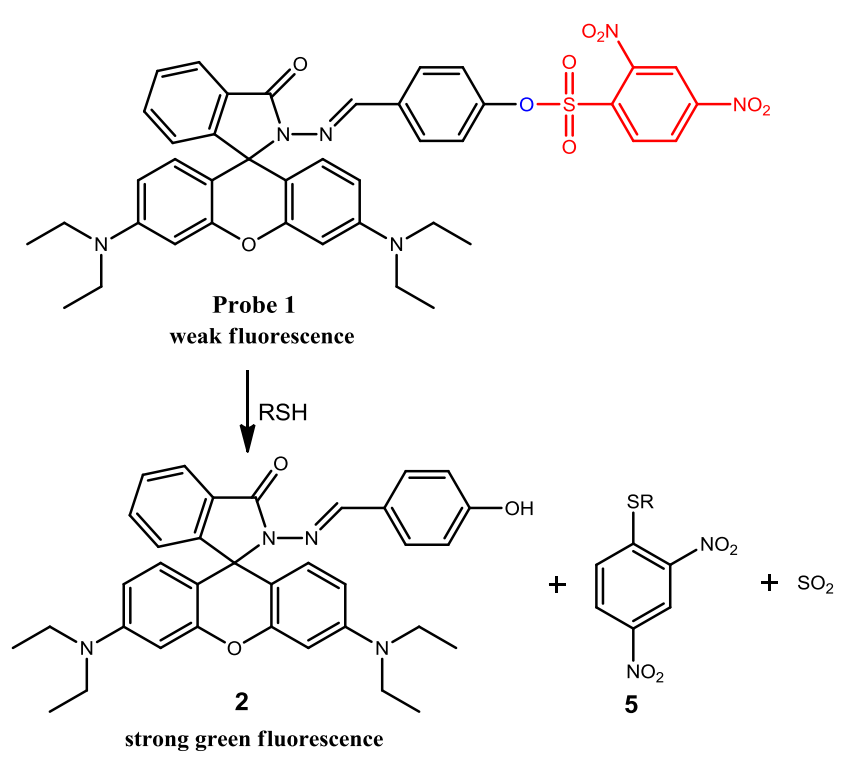

Scheme 1

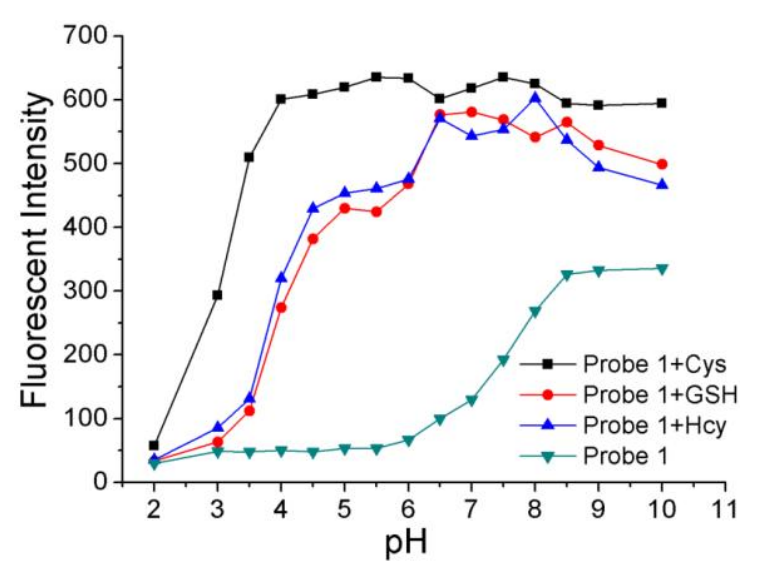

Fig. 1
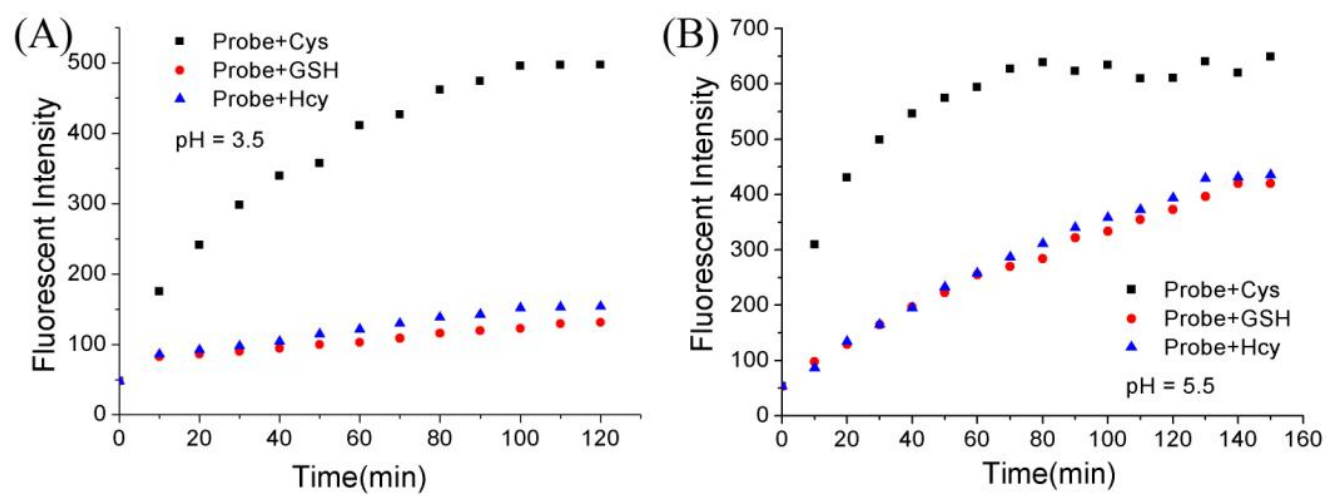

Fig. 2 

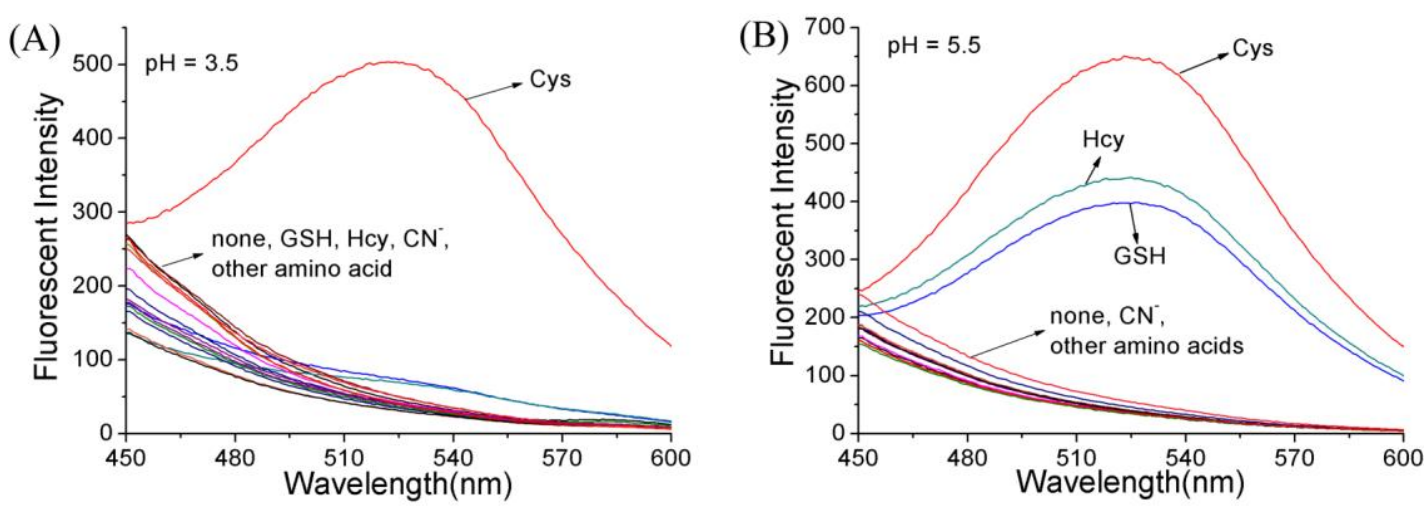

Fig. 3
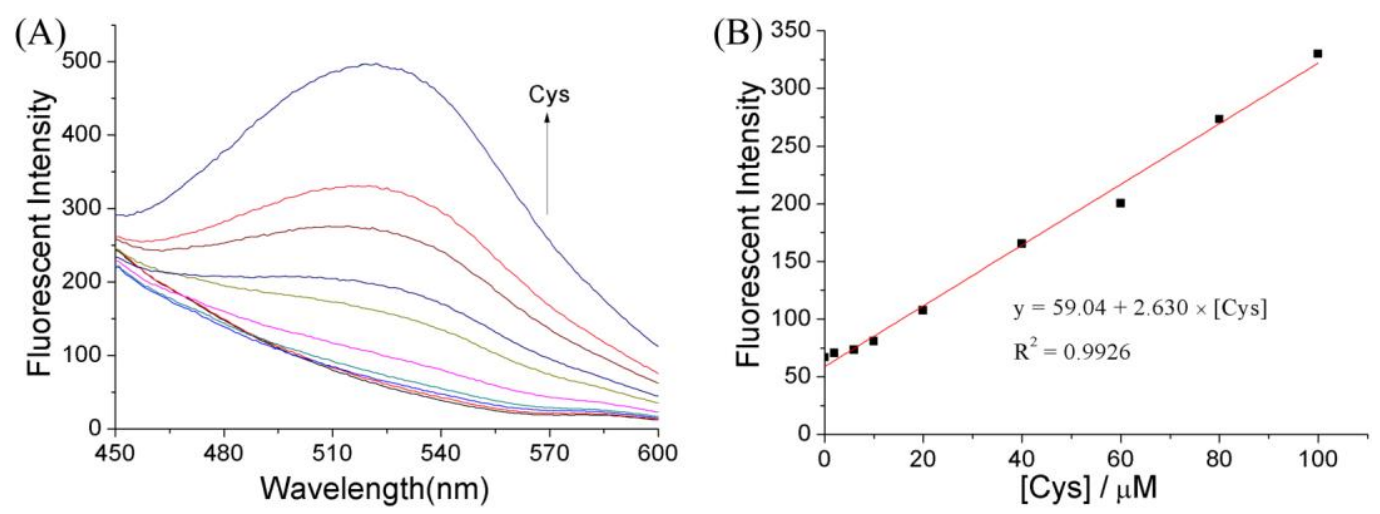

Fig. 4
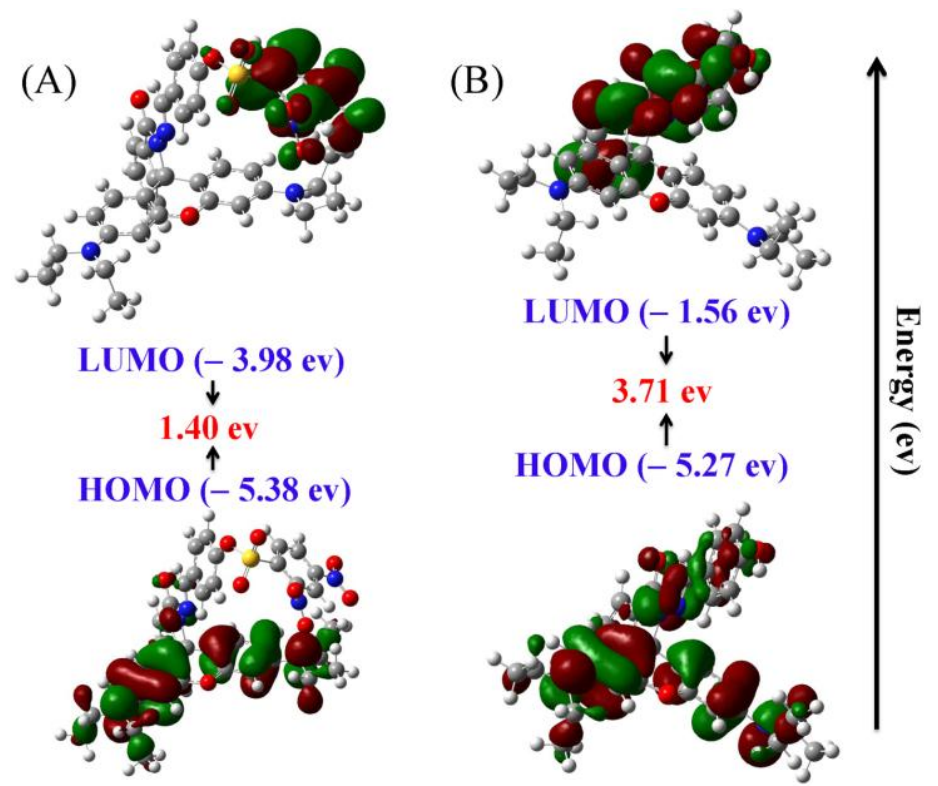

Fig. 5 


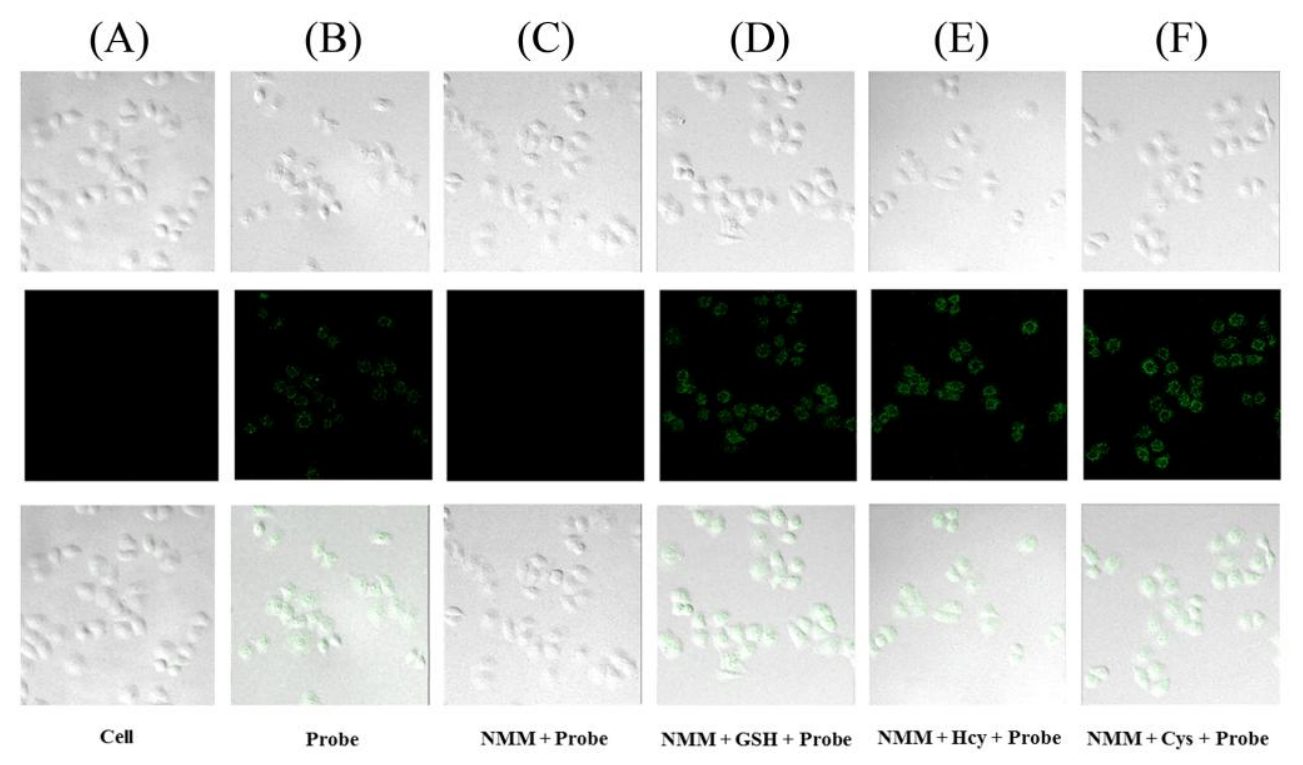

Fig. 6 


\section{Graphical abstract}
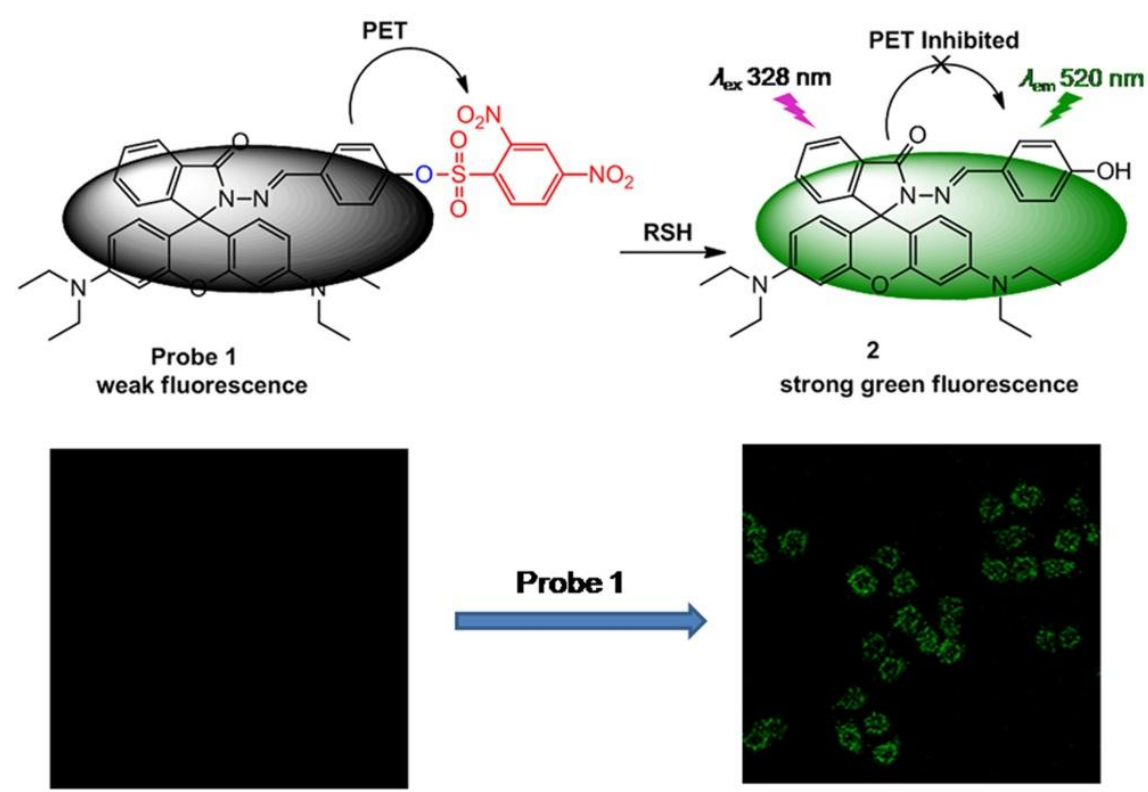